\title{
Trace geochemistry of the Early to Late Cretaceous deposits of the Grajcarek thrust-sheets - a palaeoenvironmental approach (Małe Pieniny Mts., Pieniny Klippen Belt, Poland): discussion
}

\author{
Przemysław GEDL
}

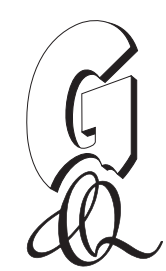

Gedl P. (2012) - Trace geochemistry of the Early to Late Cretaceous deposits of the Grajcarek thrust-sheets - a palaeoenvironmental approach (Małe Pieniny Mts., Pieniny Klippen Belt, Poland): discussion. Geol. Quart., 56 (3): 569-572, doi: 10.7306/gq.1041

Przemysław Gedl, Institute of Geological Sciences, Polish Academy of Sciences, Senacka 1, 31-002 Kraków, Poland, e-mail: ndgedl@cyf-kr.edu.pl (received: June 15,2012; accepted: July 20, 2012; first published online: September 7, 2012).
Wójcik-Tabol and Oszczypko (2012) provide data on the geochemistry (major and trace elements) of four lithostratigraphic units from the Polish part of the Pieniny Klippen Belt, including the Szlachtowa and Opaleniec formations. Their interpretations, as well as comparison with geochemical characteristics of some other lithostratigraphic units from both the Pieniny Klippen Belt and the Carpathians Flysch, support, according to these authors, a Cretaceous age for these two lithostratigraphic units. However, their interpretations, and several other aspects of their paper, in my opinion are highly arbitrary and erroneous; these are listed below.

Wójcik-Tabol and Oszczypko (2012) use various names of several formal and informal lithostratigraphical units, partly incorrectly and with different meanings. They use the a term "Black Flysch" to describe the Szlachtowa and Opaleniec formations. In fact, this term, which follows Horwitz's (1926) term "Black Cretaceous", refers to the Szlachtowa Formation only. Using this term in case of the Opaleniec Formation is incorrect - strata of this unit are neither black nor flysch. Because some other conclusions of Wójcik-Tabol and Oszczypko (2012) are partly based on incorrectly distinguished or mixed lithostratigraphic unit names, their brief characteristics are listed below:

- the Szlachtowa Formation distinguished by Birkenmajer (1977) in the Grajcarek, Czertezik, Niedzica and Branisko units is developed as dark coloured calcareous flysch up to $200 \mathrm{~m}$ thick, with characteristic sandstone layers rich in mica flakes. Initially it was believed to represent the Cretaceous (Uhlig, 1890; Horwitz, 1926; Horwitz and Rabowski, 1929) but macrofaunal data reported by Andrusov (1929) showed its Jurassic age, later confirmed by abundant, mainly Middle Jurassic fossils found in several outcrops (e.g., Birkenmajer, 1953, 1957; Birkenmajer and Pazdro, 1968; Birkenmajer et al., 1970; Birkenmajer and Myczyński, 1977; Pazdro, 1979; Dudziak, 1986; Krawczyk et al., 1992; Birkenmajer and Gedl, 2004; P. Gedl, 2007, 2008d; Barski et al., 2011). The Cretaceous age of the Szlachtowa Formation as suggested by Sikora (1962), and later by Oszczypko et al. (2004), is based on foraminifera from highly tectonized exposures in the upper course of the Sztolnia Creek (for discussion see Birkenmajer et al., 2008; Gedl, 2008a, b, c; Oszczypko et al., 2008).

- the Opaleniec Formation was distinguished by Birkenmajer (1977) in the Grajcarek Unit only; this name embraces strata previously attributed to the Cretaceous Wronine beds (Birkenmajer and Pazdro, 1968). The Jurassic age of this unit was based on fossils described and re-examined by Birkenmajer and Myczyński (1977), later confirmed by Tyszka (1995) who reported a Lower Bajocian age based on foraminifera and macrofossils (e.g., Bositra buchii), and Gedl (2008d), who suggested a Middle Jurassic age on the base of rich Bajocian-Bathonian dinoflagellate cysts found in few outcrops of this formation in the Grajcarek Unit. The Cretaceous age of the Opaleniec Formation was inferred by Oszczypko et al. (2004) on the base of foraminifera found in two samples col- 
lected from boundary sections where it adjoin Cretaceous lithostratigraphic units (see also Birkenmajer et al., 2008; P. Gedl, 2008a, b, c; Oszczypko et al., 2008).

- the Hulina Formation was distinguished by Birkenmajer (1977) in the Grajcarek Unit only; it is developed as black to brownish and greenish radiolarites and siliceous shales in the lower part (the Groń Radiolarite Member) and black to grey and greenish argillaceous shales, commonly bituminous, in the upper part of this formation (the Ubocz Shale Member). A Mid-Cretaceous age for this formation is commonly accepted (e.g., Sikora, 1962; Birkenmajer, 1965; Birkenmajer and Pazdro, 1968; E. Gedl, 2007). Wójcik-Tabol and Oszczypko (2012) use the term "Cenomanian radiolarian shales" for this formation.

Geochemical studies of sedimentary rocks (including particular element contents, their ratios, clay mineral contents) can be successfully used as indicators of a wide spectrum of palaeoenvironmental conditions. For correlation of strata, however, their use is appropriate only within a known lithostratigraphic framework in the same basin system (e.g., Gucwa, 1990 and references therein). Neither can similarities of geochemical characteristics of various rock bodies be treated as direct indications of the same age, nor do such differences directly indicate the various ages of these deposits. Wójcik-Tabol and Oszczypko (2012) interpreted their results of geochemical studies of the deposits in question in support of a Cretaceous age for the Szlachtowa and Opaleniec formations. However, they did this arbitrarily: similarities of geochemical parameters between particular rocks are treated as an argument for coeval age, whereas they regarded differences as a reflection of different environments. This arbitrary approach may be exemplified where some element ratios (e.g., Zr, Ti, Rb, Mo, $\mathrm{Zn}, \mathrm{Cu}, \mathrm{As}, \mathrm{V}, \mathrm{Ni}$ ) from the Cretaceous Hulina Formation (Cenomanian radiolarian shales) are compared (p. 183-184).

Other similarities in geochemical proxies (mainly concentrations of "immobile" elements - $\mathrm{Zr}$, Ti, $\mathrm{Rb}, \mathrm{Nb}$ ), which according to Wójcik-Tabol and Oszczypko (2012, p. 182) reflect a coeval age, refer to similar geological structures of remote source areas such as the Czorsztyn Ridge (supplying the Grajcarek Basin) and the northern margin of the Carpathian Basin that sourced the Lhoty Beds of the Silesian Basin. Meanwhile, significant differences in geochemical parameters noted by these authors from the Hulina Formation in various exposures did not lead these authors to a conclusion of different ages.

An example the risks involved in estimating the rock age on the base of geochemical data is provided by comparison of the results of Wójcik-Tabol and Oszczypko (2012, e.g., table 3) with the results obtained by Gucwa (1990, table 8) from the Carpathians Flysch. For example, mean values of $\mathrm{V}$ from the Szlachtowa Formation (130 ppm; 157 ppm in the Opaleniec Formation) correlate with that from the lower part of the Oligocene Menilite Beds of the Silesian Nappe (138 ppm); mean values of V in Cretaceous units of the Silesian Nappe oscillate between 20 and $97 \mathrm{ppm}$. The mean content of $\mathrm{Ni}$ (59 ppm in the Szlachtowa and Opaleniec formations) resembles that from the Upper Eocene/Lower Oligocene Globigerina Marls (59 ppm): Cretaceous units of the Silesian Nappe show means from 3 to $46 \mathrm{ppm}$. On the other hand, $\mathrm{Cr}$ of the Szlachtowa (84.8 ppm) and Opaleniec (93.18 ppm) formations show the closest mean values to the that of the Verovicé Beds (86 ppm).

The same refers to age conclusions on the basis of clay mineral assemblages. According to Wójcik-Tabol and Oszczypko (2012, p. 181) "The Szlachtowa and Opaleniec formations contain clay mineral assemblages including illite/smectite and kaolinite, similar to the Lhota Fm. of the Silesian Nappe and the Kapuśnica Fm. of the Pieniny Klippen Belt". Apart from the fact that many flysch deposits may possess a similar composition of clay mineral assemblages, these authors did not took into account that ratios of particular clay minerals are commonly related not only to syn-sedimentary conditions but also to post-sedimentary diagenesis. Kaolinite commonly becomes illitised, especially in case of diagenetically mature rocks (e.g., Środoń et al., 2006), which according to Wójcik-Tabol and Oszczypko (2012, p. 177) is the case in the Szlachtowa Formation.

Another controversial problem refers to the anoxic conditions that according to Wójcik-Tabol and Oszczypko (2012) characterized the depositional environment of the Szlachtowa and Opaleniec formations. They suggest a correlation of these two formations with Oceanic Anoxic Event 1 sensu Schlanger and Jenkyns (1976). Acceptance of such a correlation would indicate the existence of over 200 metres thickness of anoxic deposits! Wójcik-Tabol and Oszczypko (2012, p. 182) characterize the sedimentary setting of the Szlachtowa and Opaleniec formations as "strongly anoxic". Wójcik-Tabol and Oszczypko (2012) do not explain how the "light grey, bioturbated" Fleckenmergel facies of the Opaleniec Formation can be deposited in an anoxic environment; the same refers to the benthic faunas, regardless of their ages. The Jurassic benthic fauna in question points at rather stressed bottom conditions, possibly related to a dysoxic environment, but definitely not anoxic (e.g., Tyszka, 1994a; Birkenmajer and Tyszka, 1996). The Fleckenmergel facies of the Opaleniec Formation, so typical of the Jurassic, is also not indicative of anoxic bottom environments (e.g., Tyszka, 1994b, 1995). Anoxic conditions can be suggested for the sedimentary setting of the mid-Cretaceous Hulina Formation - e.g., E. Gedl (2007) reported amorphous organic matter (typical of anoxic environments) from the Hulina Formation at Szczawnica-Rzeźnia. This justifies correlation of the Hulina Formation with the mid-Cretaceous Barnasiówka Radiolarian Shale Formation of the Silesian Nappe (see Bąk et al., 2001).

Another problem relates to the "similarity" of the Jurassic Szlachtowa and Opaleniec formations with Cretaceous informal lithostratigraphic units of the Carpathians Flysch: the Spas Shale and the Veřovicé Beds, which according to Wójcik-Tabol and Oszczypko (2012, p. 181) provide evidence of a Cretaceous age of the Szlachtowa and Opaleniec formations. In my opinion, the above mentioned Carpathian Flysch units are different, both in lithology and palaeontological content. The Spas Shales (Barremian-Albian of the Skole Nappe) are dark grey and black, mainly non-calcareous shales with siderites; they show no flysch character. A similar hemipelagic character is shown by the Veřovicé Beds (Barremian-lower Aptian of the Silesian and Subsilesian nappes), which consist 
of black, siliceous, typically thinly-splitting, mainly non-calcareous shales (e.g., Gucik, 1963); rare intercalations of thin silicified sandstone layers occur (e.g., Unrug, 1969; Ślączka and Kaminski, 1998). The Szlachtowa Formation is a flysch deposit, with blackish marly shales and very characteristic thin-bedded sandstones rich in mica flakes. The Opaleniec Formation, in turn, shows completely no lithological similarities to the Spas Shales and the Veřovicé Beds, being rather a pale-coloured Fleckenmergel facies than a black shale deposit. There are also no similarities in palaeontological content. The Pieniny Klippen Belt formations contain rich and diverse Jurassic fossils including rare ammonites (see Birkenmajer et al., 2008) whereas the Spas Shales and Veřovicé Beds have yielded Cretaceous fossils (e.g., Geroch and Nowak, 1963; Gucik, 1963; Kotlarczyk, 1979; Szymakowska, 1981). This difference is most pronounced when dinoflagellate cysts from the deposits in question are compared: the Szlachtowa and Opaleniec formations have yielded rich and diverse Middle Jurassic assemblages (Gedl, 2008d) whereas the Flysch Carpathian units contain very rich and diverse Cretaceous assemblages (P. Gedl, 1997; E. Gedl, 1999).

\section{REFERENCES}

ANDRUSOV D. (1929) - Notes sur la géologie des Carpathes du Nord-Ouest. IV. Les klippes Piénines. Vestnik Statního Geologického Ústavu „SR (Praha), 5: 327-342.

BARSKI M., MATYJA B. A., SEGIT T. and WIERZBOWSKI A. (2011) O wieku tzw. ,czarnego fliszu” (formacja szlachtowska) w Pieninach: nowe fakty a stare kontrowersje. In: Jurassica IX (eds. B.A. Matyja, A. Wierzbowski and P. Ziółkowski): 72-75. Materiały konferencyjne, Małogoszcz, 06-08 września 2011.

BĄK K., BǍK M. and PAUL Z. (2001) - Barnasiówka Radiolarian Shale Formation - a new lithostratigraphic unit in the Upper Cenomanian-lowermost Turonian of the Polish Outer Carpathians (Silesian Series). Ann. Soc. Geol. Pol., 71: 75-103.

BIRKENMAJER K. (1953) - Preliminary revision of the stratigraphy of the Pieniny Klippen Belt series in Poland. Bull. Acad. Pol. Sc., Cl. III, 1: 271-274.

BIRKENMAJER K. (1957) - Sedimentary characteristics of the Flysch-Aalenian in the Pieniny Klippen Belt (Central Carpathians). Bull. Acad. Pol. Sc., Cl. III, 5: 451-456.

BIRKENMAJER K. (1965) - Outlines of the geology of the Pieniny Klippen Belt of Poland (in Polish with English summary). Ann. Soc. Géol. Pol., 35: 327-407.

BIRKENMAJER K. (1977) - Jurassic and Cretaceous lithostratigraphic units of the Pieniny Klippen Belt, Carpathians, Poland (in Polish with English summary). Studia Geol. Pol., 45.

BIRKENMAJER K. and GEDL P. (2004) - Dinocyst ages of some Jurassic strata, Grajcarek Unit at Sztolnia Creek, Pieniny Klippen Belt (Poland). Studia Geol. Pol., 123: 245-277.

BIRKENMAJER K. and MYCZYŃSKI R. (1977) - Middle Jurassic deposits and fauna of the Magura Succession, near Szlachtowa, Pieniny Klippen Belt (Carpathians). Acta Geol. Pol., 27 (3): 387-400.

BIRKENMAJER K. and PAZDRO O. (1968) - On the so-called "Sztolnia beds" in the Pieniny Klippen Belt of Poland (in Polish with English summary). Acta Geol. Pol., 18 (2): 325-365.

BIRKENMAJER K. and TYSZKA J. (1996) - Palaeoenvironment and age of the Krzonowe Formation (marine Toarcian-Aalenian), Pieniny Klippen Belt, Carpathians. Studia Geol. Pol., 109: 7-42.

BIRKENMAJER K., DUDZIAK J. and JEDNOROWSKA A. (1970) Subsurface geological structure of the northern boundary fault zone of the Pieniny Klippen Belt at Szczawnica, Carpathians (in Polish with English summary). Studia Geol. Pol., 61: 7-36.

BIRKENMAJER K., GEDL P., MYCZYŃSKI R. and TYSZKA J. (2008) "Cretaceous Black Flysch" in the Pieniny Klippen Belt, West Carpathians: a case of geological misinterpretation. Cret. Res., 29 (3): 535-549.

DUDZIAK K. (1986) - Calcareous nannoplankton from the Szlachtowa Formation, Jurassic, of Sztolnia Creek, Pieniny Klippen Belt, Carpathians (in Polish with English summary). Studia Geol. Pol., 88: $135-141$.
GEDL E. (1999) - Lower Cretaceous palynomorphs from the Skole nappe (Outer Carpathians, Poland). Geol. Carpath., 50: 75-90.

GEDL E. (2007) - Lower Cretaceous dinocyst stratigraphy and palynofacies of the Grajcarek Unit, Pieniny Klippen Belt, West Carpathians, Poland. Studia Geol. Pol., 127: 71-100.

GEDL P. (1997) - Palynological study of an olistolith from the so-called Sucha Formation, Zawoja IG-1 borehole (Flysch Carpathians, Poland): age and palaeoenvironment. Ann. Soc. Geol. Pol., 67 (2-3): 203-215.

GEDL P. (2007) - Organic-walled Dinoflagellate cysts from some Jurassic and Cretaceous strata of the Grajcarek Unit at Hałuszowa, Pieniny Klippen Belt (West Carpathians, Poland). Studia Geol. Pol., 127: 101-117.

GEDL P. (2008a) - Comments for discussion on biostratigraphy of the so-called "black flysh" of the Pieniny Klippen Belt in Poland (in Polish). Prz. Geol., 56 (3): 212-220.

GEDL P. (2008b) - The age of the Szlachtowa Formation (the so-called "black flysh") and the Opaleniec Formation (Pieniny Klippen Belt, Poland) based on dinoflagellate cyst studies (in Polish). Prz. Geol., 56 (3): $245-252$.

GEDL P. $(2008 c)$ - One more time on the so-called "black flysh" of the Pieniny Klippen Belt in Poland (in Polish). Prz. Geol., 56 (6): $458-459$.

GEDL P. (2008d) - Organic-walled dinoflagellate cyst stratigraphy of dark Middle Jurassic marine deposits of the Pieniny Klippen Belt, West Carpathians. Studia Geol. Pol., 131: 7-227.

GEROCH S. and NOWAK W. (1963) - Lower Cretaceous in Lipnik near Bielsko, Western Carpathians (in Polish with English summary). Ann. Soc. Géol. Pol., 33: 241-264.

GUCIK S. (1963) - Profile of the Lower Cretaceous from Bełwin in the Przemyśl Carpathians (in Polish with English summary). Kwart. Geol., 7 (2): 257-268.

GUCWA I. (1990) - Studies of geochemical correlation of the Polish Carpathian flysch sediments (in Polish with English summary). Prace Państw. Inst. Geol., 128: 1-63.

HORWITZ L. (1926) - Compte-rendu des recherches géologiques, éxecutées en 1925 sur le territoire des feuilles "Szczawnica" et "Nowy Targ” (in Polish with French summary). Posiedz. Nauk. Państw. Inst. Geol., 14: 15-16.

HORWITZ L. and RABOWSKI F. (1929) - Excursion dans les Piénines (Karpates polonaises) de la Société Géologique Polonaise (18-21 V. 1929) (in Polish with French summary). Ann. Soc. Géol. Pol., 6: 109-156.

KRAWCZYK A.J., KROBICKI M. and SŁOMKA T. (1992) - Belemnites from the Szlachtowa Formation (Middle Jurassic), Pieniny Klippen Belt, Carpathians. Bull. Pol. Acad. Sc., Earth Sc., 40: 1-7.

KOTLARCZYK J. (1979) - Wprowadzenie do stratygrafii jednostki skolskiej Karpat fliszowych. In: Badania Paleontologiczne Karpat 
Przemyskich. Materiały 4 Krajowej Konferencji Paleontologów. Przemyśl, 1979. Wyd. AGH, Kraków: 14-26.

OSZCZYPKO N., MALATA E., ŠVÁBENICKÁ L., GOLONKA J. and MARKO F. (2004) - Jurassic-Cretaceous controversies in the Western Carpathian Flysch: the "black flysch" case study. Cretaceous Res., 25: $89-113$.

OSZCZYPKO N., GOLONKA J. and MALATA E. (2008) - Replay to comments for discussion on biostratigraphy of the so-called "black flysh" of the Pieniny Klippen Belt in Poland (in Polish). Prz. Geol., 56 (3): $221-224$.

PAZDRO O. (1979) - Microfauna from the Opaleniec Formation (Middle Jurassic), Pieniny Klippen Belt of Poland, Carpathians (in Polish with English summary). Studia Geol. Pol., 61: 105-128.

SCHLANGER S.O. and JENKYNS H. C. (1976) - Cretaceous oceanic anoxic events: causes and consequences. Geol. Mijn., 55: 179-184.

SIKORA W. (1962) - New data on the geology of the Pieniny Klippen Belt. Bull. Acad. Polon. Sc., Sér. Sc. Géol. Géogr., 10: 203-211.

SZYMAKOWSKA F. (1981) - Stratigraphy of the Lower Cretaceous deposits of the Outer Flysch Carpathians based on ammonites (in Polish with English summary). Biul. Państw. Inst. Geol., 331: 57-68.

ŚLĄCZKA A. and KAMINSKI M. A. (1998) - A guidebook to excursions in the Polish Flysch Carpathians. Grzybowski Found. Spec. Publ., 6: $1-173$.

ŚRODOŃ J., KOTARBA M., BIROŇ A., SUCH P., CLAUER N. and WÓJTOWICZ A. (2006) - Diagenetic history of the Podhale-Orava
Basin and the underlying Tatra sedimentary structural units (Western Carpathians): evidence from XRD and K-Ar of illite-smectite. Clay Miner., 41: 751-774.

TYSZKA J. (1994a) - Response of Middle Jurassic benthic foraminiferal morphogroups to dysoxic/anoxic conditions in the Pieniny Klippen Basin, Polish Carpathians. Palaeogeogr. Palaeoclimatol. Palaeoecol., 110: $55-81$.

TYSZKA J. (1994b) - Palaeoenvironmental implications from ichnological and microfaunal analyses of Bajocian spotty carbonates, Pieniny Klippen Belt, Polish Carpathians. Palaios, 9: 175-187.

TYSZKA J. (1995) - Mid-Jurassic paleoenvironment and benthic communities in the Klippen and Magura Basins, Pieniny Klippen Belt, Poland. Ph.D. Thesis, Institute of Geological Sciences, Polish Academy of Sciences, Kraków.

UHLIG V. (1890) - Ergebnisse geologischer Aufnahmen in den westgalizischen Karpathen. II. Th. Der pieninische Klippenzug. Jb. geol. R.-Anstalt (Wien), 40: 559-824.

UNRUG R. (1969) - Wiadomości ogólne. In: Przewodnik geologiczny po zachodnich Karpatach fliszowych (ed. R. Unrug): 9-58. Wyd. Geol., Warszawa.

WÓJCIK-TABOL P. and OSZCZYPKO N. (2012) - Trace geochemistry of the Early to Late Cretaceous deposits of the Grajcarek thrust-sheets - a palaeoenvironmental approach (Małe Pieniny Mts., Pieniny Klippen Belt, Poland). Geol. Quart., 56 (1): 169-186. 